\title{
Commentary: Vitamin D and pancreatic cancer: a pooled analysis from the pancreatic cancer case-control consortium
}

\author{
Salvatore Chirumbolo* \\ Department of Medicine, University of Verona, Verona, Italy \\ Keywords: cancer, pancreatic neoplasms, vitamin D, vitamin D deficiency, case reports
}

\section{A commentary on}

Vitamin D and pancreatic cancer: a pooled analysis from the pancreatic cancer case-control consortium

by Waterhouse M, Risch HA, Bosetti C, Anderson KE, Petersen GM, Bamlet WR, et al. Ann Oncol (2015) 26:1776-83. doi:10.1093/annonc/mdv236

\section{OPEN ACCESS}

Edited by:

Michele Caraglia,

Second University of Naples, Italy

Reviewed by:

Carsten Carlberg,

University of Eastern Finland, Finland

Jennifer Wu,

Medical University of South Carolina,

USA

*Correspondence:

Salvatore Chirumbolo

salvatore.chirumbolo@univr.it

Specialty section:

This article was submitted to Cancer Endocrinology, a section of the journal Frontiers in Oncology

Received: 19 May 2015

Accepted: 02 July 2015

Published: 06 August 2015

Citation:

Chirumbolo S (2015) Commentary: Vitamin D and pancreatic cancer: a pooled analysis from the pancreatic

cancer case-control consortium.

Front. Oncol. 5:160.

doi: 10.3389/fonc.2015.00160
Waterhouse et al. criticized the association between vitamin $\mathrm{D}$ intake and the prevention of pancreatic cancer (1), an association that has been thoroughly reviewed in recent years $(2,3)$. Yet, randomized controlled clinical trials (RCTs) very rarely produced encouraging and reliable results on the field (4-7). Negative evidence in animal models and experimental studies $(8,9)$ should suggest that the chemopreventive role of $1,25(\mathrm{OH})_{2} \mathrm{D}_{3}$ deserve particular attention when dietary vitamin $\mathrm{D}_{3}$ is considered (10). Best correlations were reported on vitamin $\mathrm{D}_{3}$ deficiency and cancer malignancy (11-14) or on frequent dietary intake of vitamin $\mathrm{D}_{3}$ and tumor prevention (15). The chemopreventive role might closely depend on plasma bioavailability of $25(\mathrm{OH}) \mathrm{D}_{3}$ and genetic polymorphism of vitamin D receptor (VDR) $(16,17)$. Physicians are asking whether vitamin $\mathrm{D}_{3}$ supplementation may really contribute in preventing cancer $(18,19)$ and, at the same time, they suggested recommendations to fortify foods with supplemented vitamin $\mathrm{D}_{3}$, to achieve optimal levels of plasma $25(\mathrm{OH}) \mathrm{D}_{3}(20,21)$.

Waterhouse et al. showed that cancer risk increased with higher levels of vitamin D intake, although they did not exclude the possibility that vitamin D obtained through ultraviolet exposure has a beneficial effect (1). In the future, $25(\mathrm{OH}) \mathrm{D}_{3}$ may become of major importance in assessing the role of the plasmatic content of vitamin $\mathrm{D}_{3}$ to prevent chronic diseases and cancer. Dietary vitamin $\mathrm{D}_{3}$ exhibited the same anti-cancer activity than $1,25(\mathrm{OH})_{2} \mathrm{D}_{3}$ in mice (9), a chemically modified form of $25(\mathrm{OH}) \mathrm{vitD}_{3}$ exerts a chemotherapeutic effect on neuroblastoma xenograft mouse model (22), an imbalance in plasma availability of $25(\mathrm{OH}) \mathrm{D}_{3}$ is considered a risk factor for carcinoma (23) and $25(\mathrm{OH}) \mathrm{D}_{3}$, likewise $1,25(\mathrm{OH})_{2} \mathrm{D}_{3}$, exerts an anti-inflammatory effect (24-26). Most of the recent evidence should suggest that plasma level of $25(\mathrm{OH}) \mathrm{D}_{3}$ has a fundamental role in warranting protection against chronic immune disorders and cancer (27). However, any approach to enhance $25(\mathrm{OH}) \mathrm{D}_{3}$ bioavailability with diet does not appear sufficient to improve vitamin $\mathrm{D}_{3}$-related outcome, due to genetic variability within the population (28). This evidence may appear therefore quite discouraging. Physicians are wondering how to focus onto vitamin $\mathrm{D}_{3}$ dietary intake to prevent chronic immune disorders and cancer. Yet, a proper determination of plasmatic $25(\mathrm{OH}) \mathrm{D}_{3}$ metabolites is highly recommended $(29,30)$. Clinical chemists have some difficulty in evaluating plasmatic $1,25(\mathrm{OH})_{2} \mathrm{D}_{3}$, particularly because it is rapidly degraded by 24 -hydroxylases. Conversely, $25(\mathrm{OH}) \mathrm{D}_{3}$ biochemical activity should be attributed fundamentally to the 1- $\alpha$-hydroxylated form, 
a) The population undergoing vitamin D3 supplementation: this point should be addressed by considering the main geographical area and whether population is coming from developing or industrialized countries (this fact should focus on the dietary habit), their sex, their age

b) Genetic polymorphism and mutational analysis: particular genetic polymorphism for VDR should be highlighted (48-50). Moreover, genetic mutations for P450 cytochromes (particularly for CYP24A1) should be investigated $(51,52)$

c) Metabolic homeostatic balance: particular importance should be given to the metabolic homeostatic machinery held by the subject prior to his intake of vitamin $\mathrm{D}_{3}$ (calcidiol level, presence of insulin resistance or metabolic syndrome, metabolic markers, etc.)

d) Diet survey: depending on the diet habit and life style, vitamin $D_{3}$ supplementation might be accordingly adjusted, for a better performance

Analytical stage

e) Data on vitamin $D_{3}$ availability: pharmacokinetics of vitamin $D_{3}$, particularly when in association with chemopreventive drugs (53) should be known. A proper dosage of plasmatic calcidiol should be performed. A reappraisal on calcitriol determination should be conducted

Post-analytical stage

f) Prospective studies and epidemiology: further detailed studies on the association between vitamin $\mathrm{D}_{3}$ dietary intake and cancer development should give a sound contribution for the comprehension of the chemopreventive role of vitamin $D_{3}$

yet actually a more complex mechanism, involving multiple enzyme activity by $\mathrm{P} 450$ cytochromes and different metabolites, has been recently reviewed in Ref. (31). This should oblige nutritionists to be more cautious about the role of vitamin $D_{3}$ supplementation in cancer prevention. Active vitamin $\mathrm{D}_{3}$ is a shortlived, potent hormonal molecule, whose efficacy seems to depend on the homeostatic level of circulating and available $25(\mathrm{OH}) \mathrm{D}_{3}$. The activity of the $25(\mathrm{OH}) \mathrm{D}_{3}$, is increased principally by the action of CYP27B1 but recent evidence has interestingly reported that a synthetic analog of $25(\mathrm{OH}) \mathrm{D}_{3}$, i.e., 5-hydroxy-16-ene-23yne- $\mathrm{D}_{3}$, is neither modulated by CYP27B1 nor by CYP24A1 and expressed a potent anti-proliferative effect likewise $1,25(\mathrm{OH})_{2} \mathrm{D}_{3}$ (32). Furthermore, the use of synthetic analogs of $1,25(\mathrm{OH})_{2} \mathrm{D}_{3}$ appears quite promising in this field (33). Further, RCTs are needed to shed a light on the availability of newly introduced synthetic active forms of vitamin $\mathrm{D}_{3}$ for cancer prevention. The evidence should suggest that a possible way to enhance the anticancer activity of vitamin $\mathrm{D}_{3}$ is to increase $1,25(\mathrm{OH})_{2} \mathrm{D}_{3}$ effect by reducing the inhibitory action of CYP24A1, with molecules such as KD-35 or 4,5,6,7-tetrabromobenzimidazole (TBBz). This apparently simplistic point of view appeared quite encouraging $(34,35)$.

There are very few reports suggesting the possibility, through dietary intake, to improve the activity of $1,25(\mathrm{OH})_{2} \mathrm{D}_{3}$ as an immune cytokine and/or an hormone. CYP24A1 inhibitors, such as the isoflavone genistein, could be theoretically assumed with diet and they might potentiate the effect of $1,25(\mathrm{OH})_{2} \mathrm{D}_{3}$ in the immune response against cancer, although further randomized controlled trials are requested $(36,37)$.

Therefore, how to perform a correct dietary recommendation to promote vitamin $\mathrm{D}_{3}$ as a possible chemopreventive molecule? Western diet might induce or promote tumors, particularly when

\section{References}

1. Waterhouse M, Risch HA, Bosetti C, Anderson KE, Petersen GM, Bamlet WR et al. Vitamin D and pancreatic cancer: a pooled analysis from the pancreatic deficient or lacking vitamin $\mathrm{D}_{3}(38,39)$. This should suggest why most of Western populations, living in industrialized countries, are often vitamin $\mathrm{D}_{3}$ deficient. In this perspective, the initial concern is to establish the proper dietary supplementation of vita$\min \mathrm{D}_{3}$, to achieve an optimal plasmatic level of $25(\mathrm{OH}) \mathrm{D}_{3}$. However, the correct supplementation of vitamin $\mathrm{D}_{3}$ should depend on sex and age, dietary habits, level of $25(\mathrm{OH}) \mathrm{D}_{3}$, geographical areas, individual's gut microflora, and genetics of vitamin $\mathrm{D}_{3}$ metabolism (P450 cytochromes and VDR) (40-42) and this, at least theoretically, would oblige nutritionists, physicians, and caregivers to ask for a reappraisal of a Consensus Panel suggesting the proper vitamin $\mathrm{D}_{3}$ intake in relation to any of these factors (43). Due to the extreme difficulty in achieving this goal, any supplementation panel might be restricted to differential distributions in age clusters for both sexual groups and, anymore, to ensure an excess of circulating $25(\mathrm{OH}) \mathrm{D}_{3}$ in plasma. Notwithstanding, an excess of $25(\mathrm{OH}) \mathrm{D}_{3}$ may induce toxicity (44) and dampening the role of CYP24A1 in modulating $1,25(\mathrm{OH})_{2} \mathrm{D}_{3}$ activity may cause serious damage to kidney and calcium homeostasis (45). Therefore, as a severe plasma $25(\mathrm{OH}) \mathrm{D}_{3}$ deficiency is considered a bad prognostic marker for tumors $(46), 25(\mathrm{OH}) \mathrm{D}_{3}$ plasma bioavailability should be considered a major bullet point in the nutritional research of chemopreventive molecules. Yet, researchers trust the fact that vitamin $\mathrm{D}_{3}$ should be particularly useful in cancer prevention (47). Plasma $25(\mathrm{OH}) \mathrm{D}_{3}$ might be considered of major important in the future, therefore, if associated with genomics and diet habits.

A suggested work flow to assess a possible correct intake of vitamin $\mathrm{D}_{3}$, as a supplementation factor in diet to prevent cancer, should henceforth consider also a genomic and nutrition screening, most probably according to steps described in Table 1.

cancer case-control consortium. Ann Oncol (2015) 26:1776-83. doi:10.1093/ annonc/mdv236

2. Moukayed M, Grant WB. Molecular link between vitamin D and cancer prevention. Nutrients (2013) 5:3993-4021. doi:10.3390/nu5103993 
3. Bidgoli SA, Azarshab H. Role of vitamin D deficiency and lack of sun exposure in the incidence of pre-menopausal breast cancer: a case control study in Sabzevar, Iran. Asian Pac J Cancer Prev (2014) 15:3391-6. doi:10.7314/APJCP. 2014.15.8.3391

4. Cescon DW, Ganz PA, Beddows S, Ennis M, Mills BK, Goodwin PJ. Feasibility of a randomized controlled trial of vitamin $\mathrm{D}$ vs. placebo in women with recently diagnosed breast cancer. Breast Cancer Res Treat (2012) 134:759-67. doi:10.1007/s10549-012-2120-7

5. Jorde R, Grimnes G. Vitamin D and health: the need for more randomized controlled trials. J Steroid Biochem Mol Biol (2015) 148:269-74. doi:10.1016/j. jsbmb.2015.01.021

6. Avenell A, MacLennan GS, Jenkinson DJ, McPherson GC, McDonald AM, Pant PR, et al. Long-term follow-up for mortality and cancer in a randomized placebo-controlled trial of vitamin $\mathrm{D}(3)$ and/or calcium (RECORD trial). J Clin Endocrinol Metab (2012) 97:614-22. doi:10.1210/jc.2011-1309

7. Manson JE, Bassuk SS, Lee IM, Cook NR, Albert MA, Gordon D, et al. The Vitamin D and OmegA-3 TriaL (VITAL): rationale and design of a large randomized controlled trial of vitamin D and marine omega-3 fatty acid supplements for the primary prevention of cancer and cardiovascular disease. Contemp Clin Trials (2012) 33:159-71. doi:10.1016/j.cct.2011.09.009

8. Irving AA, Plum LA, Blaser WJ, Ford MR, Weng C, Clipson L, et al. Cholecalciferol or 25-hydroxycholecalciferol neither prevents nor treats adenomas in a rat model of familial colon cancer. J Nutr (2015) 145:291-8. doi:10.3945/jn.114. 204396

9. Swami S, Krishnan AV, Wang JY, Jensen K, Horst R, Albertelli MA, et al. Dietary vitamin D3 and 1,25-dihydroxyvitamin D3 3 (calcitriol) exhibit equivalent anticancer activity in mouse xenograft models of breast and prostate cancer. Endocrinology (2012) 153:2576-87. doi:10.1210/en.2011-1600

10. Chiang KC, Chen TC. The anti-cancer actions of vitamin D. Anticancer Agents Med Chem (2013) 13:126-39. doi:10.2174/187152013804487443

11. Imtiaz S, Siddiqui N. Vitamin-D status at breast cancer diagnosis: correlation with social and environmental factors and dietary intake. J Ayub Med Coll Abbottabad (2014) 26(2):186-90.

12. Alco G, Igdem S, Dincer M, Ozmen V, Saglam S, Selamoglu D, et al. Vitamin $\mathrm{D}$ levels in patients with breast cancer: importance of dressing style. Asian Pac J Cancer Prev (2014) 15:1357-62. doi:10.7314/APJCP.2014.15.3.1357

13. Zheng Y, Zhou H, Ooi LL, Snir AD, Dunstan CR, Seibel MJ. Vitamin D deficiency promotes prostate cancer growth in bone. Prostate (2011) 71:1012-21. doi:10.1002/pros.21316

14. Bade B, Zdebik A, Wagenpfeil S, Gräber S, Geisel J, Vogt T, et al. Low serum 25-hydroxyvitamin D concentrations are associated with increased risk for melanoma and unfavourable prognosis. PLoS One (2014) 9:e112863. doi:10. 1371/journal.pone.0112863

15. Huss L, Butt S, Borgquist S, Almquist M, Malm J, Manjer J. Serum levels of vitamin $\mathrm{D}$, parathyroid hormone and calcium in relation to survival following breast cancer. Cancer Causes Control (2014) 25:1131-40. doi:10.1007/s10552014-0413-3

16. Prescott J, Bertrand KA, Reid BM, Permuth-Wey J, De Vivo I, Cramer DW, et al. Evidence of differential effects of vitamin D receptor variants on epithelial ovarian cancer risk by predicted vitamin D status. Front Oncol (2014) 4:286. doi: $10.3389 /$ fonc. 2014.00286

17. Abbas S, Nieters A, Linseisen J, Slanger T, Kropp S, Mutschelknauss EJ, et al. Vitamin D receptor gene polymorphisms and haplotypes and postmenopausal breast cancer risk. Breast Cancer Res (2008) 10:R31. doi:10.1186/bcr1994

18. Pilz S, Gaksch M, Hartaigh BÓ, Tomaschitz A, März W. Vitamin D in preventive medicine. Anticancer Res (2015) 35(2):1161-70.

19. Kennel KA, Drake MT. Vitamin D in the cancer patient. Curr Opin Support Palliat Care (2013) 7:272-7. doi:10.1097/SPC.0b013e3283640f74

20. Cashman KD. Vitamin D: dietary requirements and food fortification as a means of helping achieve adequate vitamin D status. J Steroid Biochem Mol Biol (2015) 148:19-26. doi:10.1016/j.jsbmb.2015.01.023

21. Kiely M, Black LJ. Dietary strategies to maintain adequacy of circulating 25-hydroxyvitamin D concentrations. Scand J Clin Lab Invest Suppl (2012) 243:14-23. doi:10.3109/00365513.2012.681893

22. Lange TS, Zou Y, Singh RK, Kim KK, Kristjansdottir K, Sholler GL, et al. Chemotherapeutic effect of calcidiol derivative B3CD in a neuroblastoma xenograft model. Chem Biol Drug Des (2010) 76:164-73. doi:10.1111/j.17470285.2010.00988.x
23. Tuohimaa P, Lou YR. Optimal serum calcidiol concentration for cancer prevention. Anticancer Res (2012) 32(1):373-81.

24. Zoico E, Franceschetti G, Chirumbolo S, Rossi AP, Mazzali G, Rizzatti V, et al. Phenotypic shift of adipocytes by cholecalciferol and 1,25 dihydroxycholecalciferol in relation to inflammatory status and calcium content. Endocrinology (2014) 155:4178-88. doi:10.1210/en.2013-1969

25. Bakdash G, van Capel TM, Mason LM, Kapsenberg ML, de Jong EC. Vitamin D3 metabolite calcidiol primes human dendritic cells to promote the development of immunomodulatory IL-10-producing T cells. Vaccine (2014) 32:6294-302. doi:10.1016/j.vaccine.2014.08.075

26. Andrukhov O, Andrukhova O, Hulan U, Tang Y, Bantleon HP, RauschFan X. Both 25-hydroxyvitamin-D3 and 1,25-dihydroxyvitamin-D3 reduces inflammatory response in human periodontal ligament cells. PLoS One (2014) 9:e90301. doi:10.1371/journal.pone.0090301

27. Lee HJ, Muindi JR, Tan W, Hu Q, Wang D, Liu S, et al. Low $25(\mathrm{OH})$ vitamin D3 levels are associated with adverse outcome in newly diagnosed, intensively treated adult acute myeloid leukemia. Cancer (2014) 120:521-9. doi:10.1002/ cncr. 28368

28. Barry EL, Rees JR, Peacock JL, Mott LA, Amos CI, Bostick RM, et al. Genetic variants in CYP2R1, CYP24A1, and VDR modify the efficacy of vitamin D3 supplementation for increasing serum 25-hydroxyvitamin D levels in a randomized controlled trial. J Clin Endocrinol Metab (2014) 99:E2133-7. doi:10. 1210/jc.2014-1389

29. Wallace AM, Gibson S, de la Hunty A, Lamberg-Allardt C, Ashwell M. Measurement of 25-hydroxyvitamin D in the clinical laboratory: current procedures, performance characteristics and limitations. Steroids (2010) 75:477-88. doi:10. 1016/j.steroids.2010.02.012

30. Abdel-Khalik J, Crick PJ, Carter GD, Makin HL, Wang Y, Griffiths WJ. Studies on the analysis of 25-hydroxyvitamin D (3) by isotope-dilution liquid chromatography-tandem mass spectrometry using enzyme-assisted derivatisation. Biochem Biophys Res Commun (2014) 446:745-50. doi:10.1016/j.bbrc. 2014.01 .088

31. Sakaki T, Kagawa N, Yamamoto K, Inouye K. Metabolism of vitamin D3 by cytochromes P450. Front Biosci (2005) 10:119-34. doi:10.2741/1514

32. Rhieu SY, Annalora AJ, LaPorta E. Potent antiproliferative effects of 25hydroxy-16-ene-23-yne-vitamin D3 that resists the catalytic activity of both CYP27B1 and CYP24A1. J Cell Biochem (2014) 115:1392-402. doi:10.1002/jcb. 24789

33. So JY, Wahler JE, Yoon T, Smolarek AK, Lin Y, Shih WJ, et al. Oral administration of a gemini vitamin $\mathrm{D}$ analog, a synthetic triterpenoid and the combination prevents mammary tumorigenesis driven by ErbB2 overexpression. Cancer Prev Res (Phila) (2013) 6:959-70. doi:10.1158/1940-6207.CAPR-13-0087

34. Kósa JP, Horváth $\mathrm{P}$, Wölfling J, Kovács $\mathrm{D}$, Balla $\mathrm{B}$, Mátyus $\mathrm{P}$, et al. CYP24A1 inhibition facilitates the anti-tumor effect of vitamin D3 on colorectal cancer cells. World J Gastroenterol (2013) 19:2621-8. doi:10.3748/wjg.v19.i17. 2621

35. Luo W, Yu WD, Ma Y, Chernov M, Trump DL, Johnson CS. Inhibition of protein kinase CK2 reduces Cyp24al expression and enhances 1,25dihydroxyvitamin $\mathrm{D}(3)$ antitumor activity in human prostate cancer cells. Cancer Res (2013) 73:2289-97. doi:10.1158/0008-5472.CAN-12-4119

36. Lechner D, Bajna E, Adlercreutz H, Cross HS. Genistein and 17beta-estradiol, but not equol, regulate vitamin D synthesis in human colon and breast cancer cells. Anticancer Res (2006) 26(4A):2597-603.

37. Swami S, Krishnan AV, Peehl DM, Feldman D. Genistein potentiates the growth inhibitory effects of 1,25-dihydroxyvitamin D3 in DU145 human prostate cancer cells: role of the direct inhibition of CYP24 enzyme activity. Mol Cell Endocrinol (2005) 241:49-61. doi:10.1016/j.mce.2005.05.001

38. Newmark HL, Yang K, Kurihara N, Fan K, Augenlicht LH, Lipkin M. Westernstyle diet-induced colonic tumors and their modulation by calcium and vitamin $\mathrm{D}$ in $\mathrm{C} 57 \mathrm{Bl} / 6$ mice: a preclinical model for human sporadic colon cancer. Carcinogenesis (2009) 30:88-92. doi:10.1093/carcin/bgn229

39. Kurihara N, Fan K, Thaler HT, Yang K, Lipkin M. Effect of a western-style diet fortified with increased calcium and vitamin D on mammary gland of C57BL/6 mice. J Med Food (2008) 11:201-6. doi:10.1089/jmf.2007.619

40. Clarke R, Newman C, Tomson J, Hin H, Kurien R, Cox J, et al. Estimation of the optimum dose of vitamin $\mathrm{D}$ for disease prevention in older people: rationale, design and baseline characteristics of the BEST-D trial. Maturitas (2015) 80:426-31. doi:10.1016/j.maturitas.2015.01.013 
41. Lamberg-Allardt C, Brustad M, Meyer HE, Steingrimsdottir L. Vitamin D - a systematic literature review for the 5th edition of the Nordic nutrition recommendations. Food Nutr Res (2013) 3:57. doi:10.3402/fnr.v57i0.22671

42. Barker T, Rogers VE, Levy M, Templeton J, Goldfine H, Schneider ED, et al. Supplemental vitamin D increases serum cytokines in those with initially low 25-hydroxyvitamin D: a randomized, double blind, placebo-controlled study. Cytokine (2015) 71:132-8. doi:10.1016/j.cyto.2014.09.012

43. Aloia JF. Clinical review: the 2011 report on dietary reference intake for vitamin D: where do we go from here? J Clin Endocrinol Metab (2011) 96:2987-96. doi:10.1210/jc.2011-0090

44. Ketha H, Wadams H, Lteif A, Singh RJ. Iatrogenic vitamin D toxicity in an infant - a case report and review of literature. J Steroid Biochem Mol Biol (2015) 148:14-8. doi:10.1016/j.jsbmb.2015.01.022

45. Dinour D, Beckerman P, Ganon L, Tordjman K, Eisenstein Z, Holtzman EJ. Loss-of-function mutations of CYP24A1, the vitamin D 24-hydroxylase gene, cause long-standing hypercalciuric nephrolithiasis and nephrocalcinosis. J Urol (2013) 190:552-7. doi:10.1016/j.juro.2013.02.3188

46. Finkelmeier F, Kronenberger B, Köberle V, Bojunga J, Zeuzem S, Trojan J, et al. Severe 25-hydroxyvitamin D deficiency identifies a poor prognosis in patients with hepatocellular carcinoma - a prospective cohort study. Aliment Pharmacol Ther (2014) 39:1204-12. doi:10.1111/apt.12731

47. Feldman D, Krishnan AV, Swami S, Giovannucci E, Feldman BJ. The role of vitamin D in reducing cancer risk and progression. Nat Rev Cancer (2014) 14:342-57. doi:10.1038/nrc3691

48. Wang H, Wang W, Yang D, Wang S. TaqI polymorphism of VDR gene contributes to breast cancer risk. Tumour Biol (2014) 35:93-102. doi:10.1007/ s13277-013-1011-9
49. Xu J, Li H, Gu L, Zhou X. Association between vitamin D receptor poly(A) polymorphism and breast cancer risk: a meta-analysis. Tumour Biol (2014) 35:589-93. doi:10.1007/s13277-013-1082-7

50. Luo S, Guo L, Li Y, Wang S. Vitamin D receptor gene ApaI polymorphism and breast cancer susceptibility: a meta-analysis. Tumour Biol (2014) 35:785-90. doi:10.1007/s13277-013-1107-2

51. Muindi JR, Adjei AA, Wu ZR, Olson I, Huang H, Groman A, et al. Serum vitamin $\mathrm{D}$ metabolites in colorectal cancer patients receiving cholecalciferol supplementation: correlation with polymorphisms in the vitamin $\mathrm{D}$ genes. Horm Cancer (2013) 4:242-50. doi:10.1007/s12672-013-0139-9

52. Höbaus J, Thiem U, Hummel DM, Kallay E. Role of calcium, vitamin D, and the extrarenal vitamin D3 hydroxylases in carcinogenesis. Anticancer Agents Med Chem (2013) 13:20-35. doi:10.2174/1871520611307010020

53. Kennedy DA, Cooley K, Skidmore B, Fritz H, Campbell T, Seely D. Vitamin D: pharmacokinetics and safety when used in conjunction with the pharmaceutical drugs used in cancer patients: a systematic review. Cancers (Basel). (2013) 5:255-80. doi:10.3390/cancers5010255

Conflict of Interest Statement: The author declares that the research was conducted in the absence of any commercial or financial relationships that could be construed as a potential conflict of interest.

Copyright (C) 2015 Chirumbolo. This is an open-access article distributed under the terms of the Creative Commons Attribution License (CC BY). The use, distribution or reproduction in other forums is permitted, provided the original author(s) or licensor are credited and that the original publication in this journal is cited, in accordance with accepted academic practice. No use, distribution or reproduction is permitted which does not comply with these terms. 